\title{
A possible mechanism of inhibition of U87MG and SH-SY5Y cancer cell proliferation by diallyl trisulfide and other aspects of its activity
}

\author{
Halina Jurkowska ${ }^{1} \oplus$ - Maria Wróbel ${ }^{1} \cdot$ Marta Kaczor-Kamińska $^{1} \cdot$ \\ Ewa Jasek-Gajda ${ }^{2}$
}

Received: 30 March 2017 / Accepted: 18 August 2017 / Published online: 29 August 2017

(C) The Author(s) 2017. This article is an open access publication

\begin{abstract}
The study was conducted to elucidate the mechanism of antiproliferative and antioxidative action of diallyl trisulfide (DATS), a garlic-derived organosulfur compound. Changes in the L-cysteine desulfuration, and the levels of cystathionine and non-protein thiols in DATS-treated human glioblastoma (U87MG) and neuroblastoma (SH-SY5Y) cells were investigated. The inhibition of proliferation of the investigated cells by DATS was correlated with an increase in the inactivated form of Bcl-2. In U87MG cells, an increased level of sulfane sulfur and an increased activity of 3-mercaptopyruvate sulfurtransferase (MPST) and rhodanese, the enzymes involved in sulfane sulfur generation and transfer, suggest that DATS can function as a donor of sulfane sulfur atom, transferred by sulfurtransferases, to sulfhydryl groups of cysteine residues of Bcl-2 and in this way lower the level of active form of Bcl-2 by $S$-sulfuration. Diallyl trisulfide antioxidative effects result from an increased level of cystathionine, a precursor of cysteine, and an increased glutathione level. MPST and rhodanese, the
\end{abstract}

Handling Editor: G. J. Peters.

Halina Jurkowska

halina.jurkowska@uj.edu.pl

Maria Wróbel

mbwrobel@cyf-kr.edu.pl

Marta Kaczor-Kamińska

marta.b.kaczor@gmail.com

Ewa Jasek-Gajda

ewa.jasek@uj.edu.pl

1 Chair of Medical Biochemistry, Jagiellonian University Medical College, 7 Kopernika St, 31-034 Kraków, Poland

2 Department of Histology, Jagiellonian University Medical College, 7 Kopernika St, 31-034 Kraków, Poland level of which is increased in the presence of DATS, can serve as antioxidant proteins.

Keywords Diallyl trisulfide $\cdot$ Sulfurtransferase $\cdot$ Sulfane sulfur $\cdot$ Glutathione $\cdot$ Cancer cells

$\begin{array}{ll}\text { Abbreviations } \\ \text { DATS } & \text { Diallyl trisulfide } \\ \text { U87MG } & \text { The human glioblastoma cell line } \\ \text { SH-SY5Y } & \text { The human neuroblastoma cell line } \\ \text { CBS } & \text { Cystathionine- } \beta \text {-synthase } \\ \text { CTH } & \text { Cystathionine- } \gamma \text {-lyase } \\ \text { GSH } & \text { Reduced glutathione } \\ \text { GSSG } & \text { Oxidazed glutathione } \\ \text { Cys } & \text { L-cysteine } \\ \text { RP-HPLC } & \text { Reversed-phase high-performance liquid } \\ & \text { chromatography } \\ \text { MPST } & \text { 3-Mercaptopyruvate sulfurtransferase } \\ \text { Bcl-2 } & \text { B-cell lymphoma-2 } \\ \text { PI3 K } & \text { Phosphoinositide 3-kinase } \\ \text { AKT } & \text { Serine/threonine-specific protein kinase } \\ \text { JNK } & \text { C-jun N-terminal kinase } \\ \text { MMP } & \text { Metalloproteinase } \\ \text { ERK } & \text { Extracellular signal-regulated kinases } \\ \text { MAPK } & \text { Mitogen-activated protein kinases } \\ \text { VEGF } & \text { Vascular endothelial growth factor } \\ \text { FAK } & \text { Focal adhesion kinase } \\ \text { Src } & \text { Protein tyrosine kinase } \\ \text { HT29 } & \text { The human colon cancer cell line }\end{array}$

\section{Introduction}

Diallyl trisulfide (DATS), a sulfur compound derived from garlic, has various biological properties, such as anticancer 
(Liu et al. 2016; Pandrangi 2015; Ma et al. 2014; Hung et al. 2014; Shin et al. 2014; Zhou et al. 2009; Chandra-Kuntal et al. 2013; Wu et al. 2004; Xiao et al. 2004, 2006; Li et al. 2012; Shankar et al. 2008), antiangiogenic (Lai et al. 2015) and anti-inflammatory (Zhang et al. 2016; Kuo et al. 2013; Zeng et al. 2008) effects.

Diallyl trisulfide inhibits the growth of human cancer cells by inducing apoptosis in association with downregulation of Bcl-2 expression (Ma et al. 2014; Shin et al. 2014; Zhou et al. 2009; Li et al. 2012; Wan et al. 2013; Malki et al. 2009; Choi and Park 2012; Kim et al. 2007), induction of caspases and regulation of PI3 K/Akt and JNK pathways (Shin et al. 2014; Zhou et al. 2009; Choi and Park 2012; Seki et al. 2008; Borkowska et al. 2012). DATS-induced apoptosis of human pancreatic cancer cells is correlated with downregulation of Akt and cyclin D1 protein levels, and up-regulation of Bax, Fas, p53 and cyclin B protein levels (Ma et al. 2014). Recent studies have demonstrated the anticancer effects of DATS against breast cancer (Malki et al. 2009; Hahm and Singh 2014; Chandra-Kuntal et al. 2013; Nkrumah-Elie et al. 2012). DATS inhibits matrix metalloproteinases-2, and -9 (MMP2/9) activities and the metastasis of triple-negative breast cancer. The inhibitory effects are associated with downregulation of the transcriptional activities of NF- $\mathrm{KB}$ and ERK/MAPK signaling pathways (Liu et al. 2015). DATS suppresses the invasion of oral squamous cell carcinoma cell lines by reducing matrix MMP-9 via PI3K/AKT (Yang et al. 2012). Migration, invasion and angiogenesis of human colon cancer HT-29 cells and umbilical vein endothelial HUVEC cells are also inhibited by DATS (Lai et al. 2015). In HT29 cells, DATS inhibits migration and invasion through the inhibition of focal adhesion kinase (FAK), extracellular signal-regulated kinase, c-Jun N-terminal kinase and $\mathrm{p} 38$, which is associated with inhibition of MMP2/7/9 and VEGF. DATS affects inhibition of tumor growth, tumor weight and angiogenesis (decreasing the levels of hemoglobin) in HT29 cells (Lai et al. 2015). In human umbilical vein endothelial cells, DATS inhibits the migration and angiogenesis through FAK, Src and Ras; the secretion of VEGF is also inhibited in these cells.

Diallyl trisulfide demonstrates antioxidative effects, which are associated with the changes in the activity of antioxidant enzymes and the level of glutathione (Wu et al. 2004; Zhang et al. 2016; Zeng et al. 2008; Mostafa et al. 2016; Prabu and Sumedha 2014; Hu et al. 2007).

Diallyl trisulfide treatment resulted in increasing the levels of $\mathrm{H}_{2} \mathrm{~S}$ (Chen et al. 2016; Tsai et al. 2015; Zhao et al. 2014). DATS reacts rapidly with reduced glutathione (GSH) to release $\mathrm{H}_{2} \mathrm{~S}$ through thiol-disulfide exchange followed by allyl perthiol reduction by GSH (Liang et al. 2015). Benavides et al. (2007) first determined that DATS could be converted into $\mathrm{H}_{2} \mathrm{~S}$ by human red blood cells or by rat aorta through a thiol, mainly glutathione, -dependent mechanism.
$\mathrm{H}_{2} \mathrm{~S}$ can be generated endogenously from L-cysteine by sulfurtransferases, including gamma-cystathionase (CTH), cystathionine beta-synthase (CBS), and 3-mercaptopyruvate sulfurtransferase (MPST) in combination with cysteine aminotransferase (Liu et al. 2016; Kolluru et al. 2013; Jurkowska et al. 2014). $\mathrm{H}_{2} \mathrm{~S}$ can be oxidized to sulfane sulfur, a sulfur in the thiosulfoxide form (represented as $\mathrm{S}^{0}$ ), which plays important regulatory functions in biological systems (Toohey and Cooper 2014; Stein and Bailey 2013).

The study we have undertaken shows the effect of diallyl trisulfide on sulfane sulfur level, the activity of $\mathrm{H}_{2} \mathrm{~S}$-generating enzymes, the level of cystathionine and non-protein thiols, such as L-cysteine, L-cystine, and GSH and oxidized glutathione (GSSG), in human glioblastoma (U87MG) and neuroblastoma (SH-SY5Y) cells. We have shown that DATS results in an intensification of desulfuration pathways of L-cysteine by induction of sulfurtransferases activity, and causing an increase of the cystathionine and sulfane sulfur levels. Interestingly, we have found in this study that inhibition of U87MG and SH-SY5Y cells proliferation by DATS is also correlated with an increase in the inactivated form of $\mathrm{Bcl}-2$ and the percentage of $\mathrm{Bcl}-2$ non-expressing cells. Our results have confirmed (Jurkowska and Wróbel 2008; Jurkowska et al. 2011b) that inhibition of cell proliferation is correlated with elevation in intracellular sulfane sulfur level. The present results raise questions concerning the possible mechanism of inhibition of the Bcl-2 protein involved in the regulation of apoptosis. Our study has proven that DATS has an antioxidative effect on cancer cells by increasing the MPST and rhodanese activity and cystathionine and GSH levels.

\section{Materials and methods}

\section{Sources of chemicals}

Folin-Ciocialteau reagent, NADH, lactate dehydrogenase (LDH), pyridoxal phosphate (PLP), N-ethylmaleimide (NEM), bathophenanthrolinedisulfonic acid (BPDS), 2,4-dinitrofluorobenzene (DNFB), 1,4-dithio-bis-(2-nitrobenzoic acid) (DTT), acetonitrile, and crystal violet (N-hexamethylpararosaniline) were obtained from SigmaAldrich Corp. (St. Louis, MO, USA). Potassium cyanide (KCN) was obtained from Merck (Darmstadt, Germany), sodium 3-mercaptopyruvate, trifluoroacetic acid (TFA), and 2-mercaptoethanol from Flucka Chemie GmbH. Ne-methylL-lysine was purchased from Bachem (Bubendorf, Switzerland). Fetal bovine serum, trypsin, and penicillin/streptomycin were obtained from HyClone Laboratories (Utah, USA). The Cytotoxicity Detection Kit (LDH) was obtained from Roche Applied Science. All the other chemicals were 
of reagent grade and purchased from common commercial suppliers.

Diallyl trisulfide (DATS) was purchased from Cayman Chemical Company (Michigan, USA) and dissolved in dimethyl sulphoxide (DMSO; Sigma-Aldrich Corp., St. Louis, MO, USA), and then diluted with the medium Dulbecco's Modified Eagle's Medium (DMEM; HyClone Laboratories, Utah, USA) to the desired concentration prior to its use (the final concentration of DMSO in the medium was less than $0.1 \%)$.

\section{Cell culture}

Human U87MG (glioblastoma) and SH-SY5Y (neuroblastoma) cells were obtained from the European Collection of Cell Cultures (ECACC) and maintained at $37{ }^{\circ} \mathrm{C}$ in humidified $95 \%$ air and $5 \% \mathrm{CO}_{2}$ in DMEM supplemented with $10 \%$ fetal bovine serum (FBS), $2 \mathrm{mM}$ L-glutamine, and $1 \%$ penicillin-streptomycin (100 Units/ml penicillin and $100 \mu \mathrm{g} / \mathrm{ml}$ streptomycin).

\section{Cell homogenization}

U87MG and SH-SY5Y cells were suspended in $0.1 \mathrm{M}$ phosphate buffer $\mathrm{pH} 7.5$, in the ratio of $1 \times 10^{6}$ cells $/ 0.04 \mathrm{ml}$ of the buffer, and sonicated $3 \times 5 \mathrm{~s}$ at $4{ }^{\circ} \mathrm{C}$ (Bandelin Sonoplus GM 70). After centrifugation at $4500 \mathrm{~g}$ at $4{ }^{\circ} \mathrm{C}$ for $10 \mathrm{~min}$, the supernatant was used for the determination of protein concentration, sulfane sulfur levels and the activity of MPST, CTH, and rhodanese. For GSH, GSSG, L-cysteine, L-cystine and cystathionine, the cells were suspended in $0.1 \mathrm{ml} 10 \%$ perchloric acid/1 mM BPDS. The sediment was separated by centrifugation at $1600 \mathrm{~g}$ for $10 \mathrm{~min}$, and the supernatant was saved at $-80{ }^{\circ} \mathrm{C}$ until used for RP-HPLC analyses.

\section{Enzyme assay}

MPST activity was assayed according to the method of Valentine and Frankenfeld (1974), with some modifications as described by Wróbel et al. (2004). The enzyme activity is expressed as nmoles of pyruvate produced during 1-min incubation at $37{ }^{\circ} \mathrm{C}$ per $1 \mathrm{mg}$ of protein. Rhodanese activity was assayed by the Sorbo's method (1955), following a procedure described in Wróbel et al. (2004). The enzyme activity is expressed as nmoles $\mathrm{SCN}^{-}$formed during $1 \mathrm{~min}$ incubation at $20{ }^{\circ} \mathrm{C}$ per $1 \mathrm{mg}$ of protein. $\mathrm{CTH}$ activity was determined according to Matsuo and Greenberg (1958) as modified by Czubak et al. (2002). The enzyme activity is expressed as nmoles of $\alpha$-ketobutyrate formed during 1-min incubation at $37^{\circ} \mathrm{C}$ per $1 \mathrm{mg}$ of protein.

\section{Determination of sulfane sulfur level}

Sulfane sulfur was determined by the method of Wood (1987), based on cold cyanolysis and colorimetric detection of ferric thiocyanate complex ion, and protein was determined by the method of Lowry et al. (1951) using crystalline bovine serum albumin as a standard.

\section{Determination of GSH, GSSG, L-cysteine, L-cystine, and cystathionine levels}

RP-HPLC (Reversed-Phase High-Performance/Pressure Liquid Chromatography) method was used to determine the levels of such metabolites as L-cysteine, L-cystine, GSH and GSSG, and cystathionine in the investigated cells based on the method of Dominick et al. (2001), with some modification as described by Bronowicka-Adamska et al. (2011).

\section{Determination of cell viability}

The effect of diallyl trisulfide on cell viability was assessed by measuring the leakage of lactate dehydrogenase (LDH) from dead or dying cells using a Cytotoxicity Detection Kit (Roche) as described previously (Jurkowska et al. 2011b). The $100 \mu \mathrm{M}$ concentration of DATS that yielded LDH leakage of less than $5 \%$ was used for the experiments.

\section{Cell proliferation}

The cells were seeded on 96-well plates at a concentration of $1.2 \times 10^{3}$ cells/well (U87MG cells) or $1.5 \times 10^{3}$ cells/ well (SH-SY5Y cells) in DMEM supplemented as reported above. Following 24-h incubation, the culture medium was replaced with $100 \mu \mathrm{l}$ of complete medium with DMSO (as the control) or $100 \mu \mathrm{l}$ of medium containing $100 \mu \mathrm{M}$ DATS and the plates were cultured for 24 and $48 \mathrm{~h}$. The modified crystal violet staining method (Gillies et al. 1986) was used to determine the effect of DATS on the cell proliferation. The absorbance was measured at $540 \mathrm{~nm}$ using an Epoch Microplate Spectrophotometer (BioTek).

\section{Bcl-2 expression assay}

Bcl-2 expression was analyzed using a Muse ${ }^{\mathrm{TM}} \mathrm{Bcl}-2$ Activation Dual Detection Kit (Millipore, Billerica, MA, USA) according to the manufacturer's instruction. The assay utilizes two directly conjugated antibodies, a phospho-specific anti-phospho-Bcl-2 (Ser70)-Alexa Fluor 555 and an antiBcl-2-PECy5 conjugated antibody to measure total levels of Bcl-2 expression.

Briefly, $1 \times 10^{5}$ cells were harvested, washed twice with 1X PBS and fixed with Fixation Buffer for 5 min on ice. Following the washing step with PBS, the cells were 
resuspended in Permeabilization Buffer and incubated for 5 min on ice. After washing with PBS, the cells were resuspended in 1X Assay Buffer containing the antibody working cocktail solution and incubated for $30 \mathrm{~min}$ in the dark at room temperature. The cells were analyzed by a Muse ${ }^{\mathrm{TM}}$ Cell Analyzer and a Muse ${ }^{\mathrm{TM}}$ analysis software (Millipore).

\section{Isolation of total RNA}

Total RNA was extracted from the cells using TRIzol reagent (Invitrogen, CA, USA), according to the protocol provided by the manufacturer. The extracted RNA was suspended in ribonuclease-free water and was quantified by measuring the absorbance at $260 \mathrm{~nm}$. The integrity of the purified RNA collected by this method was confirmed by observation of the $28 \mathrm{~S}$ and $18 \mathrm{~S}$ rRNA bands after agarose gel electrophoresis.

\section{Reverse transcription of RNA}

Total RNA from the cell samples was reverse-transcribed using the GoScript ${ }^{\mathrm{TM}}$ Reverse Transcriptase according to the manufacturer's instructions (Promega Corporation). For reverse transcription (RT), $3 \mu \mathrm{g}$ of total RNA was mixed with $1 \mu$ of Oligo $\mathrm{d}(T)$ primer $(0.5 \mu \mathrm{g} / \mu \mathrm{l})$ and water pretreated with diethylpyrocarbonate $\left(\mathrm{H}_{2} \mathrm{O}-\mathrm{DEPC}\right)$ and incubated for 5 min at $70^{\circ} \mathrm{C}$. After preincubation, other components were added to this mixture: $4 \mu \mathrm{l} \mathrm{GoScript}{ }^{\mathrm{TM}} 5 \times$ Reaction buffer (Promega Corporation), $3 \mu \mathrm{l} \mathrm{MgCl}, 1 \mu \mathrm{l}$ RNase inhibitor (20 U/ $\mu \mathrm{l}), 1 \mu \mathrm{l}$ deoxyribonucleotide triphosphates (dNTPs, $10 \mathrm{mM}$ ), and $1 \mu \mathrm{l} \mathrm{GoScript}{ }^{\mathrm{TM}}$ Reverse Transcriptase (160 $\mathrm{U} / \mu \mathrm{l})$ in a total volume of $20 \mu \mathrm{l}$. The mixture was first incubated for $5 \mathrm{~min}$ at $25^{\circ} \mathrm{C}$, then for $60 \mathrm{~min}$ at $42{ }^{\circ} \mathrm{C}$, and for the final $15 \mathrm{~min}$ at $70^{\circ} \mathrm{C}$, and stored at $-20^{\circ} \mathrm{C}$.

\section{Polymerase chain reaction}

Expressions of MPST, CTH, and $\beta$-actin were analyzed by PCR. Amplification of cDNA samples was run in a $25 \mu \mathrm{l}$ reaction volume that contained the following: $2 \mu \mathrm{l}$ of synthesized cDNA, $0.2 \mu \mathrm{M}$ of each of gene-specific primer pair, $0.04 \mathrm{U} / \mu \mathrm{l}$ DNA polymerase in $10 \mathrm{mM}$ buffer Tris- $\mathrm{HCl} \mathrm{pH}$ 8.8 (supplemented with $1.5 \mathrm{mM} \mathrm{MgCl} 2,50 \mathrm{mM} \mathrm{KCl}, 0.1 \%$ Triton X-100), $0.2 \mathrm{mM}$ of each dNTPs and $\mathrm{H}_{2} \mathrm{O}$-DEPC.

For the MPST gene, PCR cycling conditions were $94{ }^{\circ} \mathrm{C}$ (5 min) for one cycle, $94{ }^{\circ} \mathrm{C}(30 \mathrm{~s}), 56^{\circ} \mathrm{C}(30 \mathrm{~s})$, and $72{ }^{\circ} \mathrm{C}$ ( $2 \mathrm{~min}$ ) for 28 cycles, with a final extension $72{ }^{\circ} \mathrm{C}$ ( $8 \mathrm{~min}$ ). Primer sequences were as follows: forward 5' CCAGGT ACCGTGAACATCCC 3', and reverse 5'ATGTACCACTCC ACCCAGGA 3' (227 bp). The MPST mRNA sequence was obtained from NCBI. These PCR conditions for the MPST gene are published for the first time in this paper.
For the $\mathrm{CTH}$ gene, after an initial $5 \mathrm{~min}$ at $94{ }^{\circ} \mathrm{C}$ denaturation, amplification was performed under the following conditions: $94{ }^{\circ} \mathrm{C}$ for $30 \mathrm{~s}, 51^{\circ} \mathrm{C}$ for $60 \mathrm{~s}$, and $72{ }^{\circ} \mathrm{C}$ for 8 min for 28 cycles, with a final incubation at $72{ }^{\circ} \mathrm{C}$ for 10 min (Jurkowska et al. 2011a). The primer sequences were as follows: forward 5'-GCAAGTGGCATCTGAATTTG-3', and reverse 5'-CCC ATTACAACATCACTGTGG-3' (301 bp) (Levonen et al. 2000).

For the $\beta$-Actin gene, after an initial $5 \mathrm{~min}$ at $94{ }^{\circ} \mathrm{C}$ denaturation, amplification was performed under the following conditions: $94{ }^{\circ} \mathrm{C}$ for $30 \mathrm{~s}, 54{ }^{\circ} \mathrm{C}$ for $30 \mathrm{~s}$, and $72{ }^{\circ} \mathrm{C}$ for 2 min for 30 cycles, with a final incubation at $72{ }^{\circ} \mathrm{C}$ for 8 min (Jurkowska et al. 2011a). The primer sequences were as follows: forward 5'-CTGTCTGGCGGCACCACC AT-3', and reverse 5'-GCAACTAAGTCATAGTCCGC-3' ( 300 bp) (Kusukawa et al. 2000).

$\beta$-Actin was used as an internal standard to normalize all the samples for potential variations in mRNA content. All PCR products were analyzed by electrophoresis on $2.0 \%$ agarose gel stained with ethidium bromide, and directly visualized under UV light and photographed.

\section{Statistical analysis}

All the experiments were repeated at least three times. The data are expressed as mean \pm standard deviation (SD). The statistical analysis was performed using the Student's $t$ test; values of $* p<0.05$ were considered to indicate statistical significance.

\section{Results}

Effect of diallyl trisulfide on the proliferation of human glioblastoma (U87MG) and neuroblastoma (SH-SY5Y) cell lines

To examine the effects of DATS on the proliferation of human cancer cells, U87MG and SH-SY5Y cells were treated with $100 \mu \mathrm{M}$ DATS and then subjected to crystal violet assay. As shown in Fig. 1, the growth of DATS-treated U87MG and SH-SY5Y cells was significantly decreased. After $24 \mathrm{~h}$ of culture, U87MG and SH-SY5Y cells proliferation decreased to about 72 and $84 \%$, respectively, as compared to the control group. After $48 \mathrm{~h}$ of culture, DATS inhibited the growth of U87MG and SH-SY5Y cells to about 74 and $48 \%$, respectively.

\section{Effect of diallyl trisulfide on the Bcl-2 expression in human glioblastoma (U87MG) and neuroblastoma (SH-SY5Y) cell lines}

A Muse ${ }^{\mathrm{TM}}$ Bcl-2 Activation Dual Detection Kit was used to measure the percentage of $\mathrm{Bcl}-2$ protein activation in 


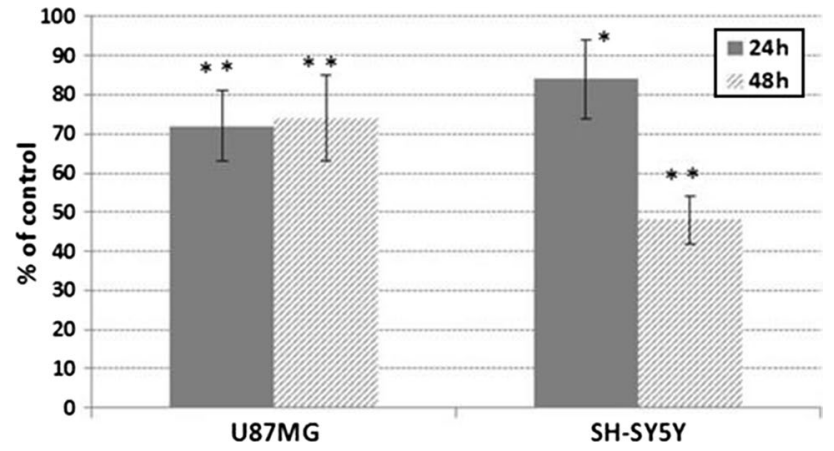

Fig. 1 Effect of diallyl trisulfide on U87MG and SH-SY5Y cells proliferation. The cells were treated with $100 \mu \mathrm{M}$ DATS for 24 and $48 \mathrm{~h}$. The results are represented as a percentage of absorbance relative to the control cells $(100 \%)$. Data represent mean $\pm \mathrm{SD}$; a statistical significance was shown as follows: $* p<0.01$; ${ }^{*} p<0.001$ (Student's $t$ test)

SH-SY5Y and U87MG cells. Figures 2 and 3 show the percentage of cells with active and inactive (phosphorylated) form of Bcl-2, and non-expressing cells. As shown in Figs. 2 and 3, diallyl trisulfide causes an increase in Bcl-2 inactivated in U87MG and SH-SY5Y cells; the active form of Bcl-2 is decreased in both cancer cell lines. Our results indicate that DATS induces apoptosis via suppression of anti-apoptotic Bcl-2.

\section{Effect of diallyl trisulfide on the sulfurtransferases activity in human glioblastoma (U87MG) and neuroblastoma (SH-SY5Y) cell lines}

As shown in Fig. 4a, $100 \mu$ M DATS caused an elevation of the MPST activity, and the sulfane sulfur level in U87MG cells after $48 \mathrm{~h}$ of culture. The rhodanese activity was also increased in the presence of DATS after 24 and $48 \mathrm{~h}$ of culture (Fig. 4a). In SH-SY5Y cells, the activity of MPST and rhodanese, and the level of sulfane sulfur were not changed under these culture conditions (Fig. 4b). The activity of gamma-cystathionase was low in both cancer cell lines, and DATS did not cause a statistically significant difference in this enzyme activity (Fig. 4a, b).

\section{Effect of diallyl trisulfide on the expression of two sulfane sulfur and hydrogen sulfide generating sulfurtransferases in human glioblastoma (U87MG) and neuroblastoma (SH-SY5Y) cell lines}

We did not observe statistically significant differences in the expression of mRNA of CTH and MPST genes in U87MG and SH-SY5Y cells after incubation with $100 \mu \mathrm{M}$ DATS (not presented data).
Effect of diallyl trisulfide on the level of non-protein thiols and cystathionine in human glioblastoma (U87MG) and neuroblastoma (SH-SY5Y) cell lines

The RP-HPLC method was used to investigate changes in the level of GSH, GSSG, L-cysteine, L-cystine, and cystathionine in U87MG and SH-SY5Y cells in the presence of diallyl trisulfide. In both cancer cell lines, an increased level of GSH and GSSG was detected after 24 and $48 \mathrm{~h}$ of culture in the presence of $100 \mu \mathrm{M}$ DATS (Tables 1,2). The intracellular level of L-cysteine in U87MG cells was higher (about $1 \mathrm{nmol} / \mathrm{mg}$, control value) (Table 1) as compared to $\mathrm{SH}-$ SY5Y cells (not detected) (Table 2). In DATS-treated SHSY5Y cells, the level of L-cystine was twofold increased as compared to the control cells (Table 2). In SH-SY5Y cells, the level of cystathionine was also increased in the presence of DATS (Table 2).

\section{Discussion}

\section{Anticancer effect of diallyl trisulfide on U87MG and SH-SY5Y cells}

Garlic-derived organosulfur compounds provide significant protection against carcinogenesis (Capasso 2013; Wallace et al. 2013). In this paper, we have demonstrated that DATS inhibits proliferation of human glioblastoma (U87MG) and neuroblastoma (SH-SY5Y) cells. Our results show once again a relationship existing between the level of sulfane sulfur and cell proliferation. From the results we can conclude that inhibition of U87MG cells growth (Fig. 1) in the presence of DATS, as well as other cysteine precursors, such as N-acetyl-L-cysteine (Jurkowska and Wróbel 2008) and D-ribose-L-cysteine (Jurkowska et al. 2011b), is closely associated with an elevated intracellular sulfane sulfur level (Fig. 4a). Studies carried out by Predmore et al. (2012a, b) in mouse models of myocardial ischemia-reperfusion injury indicated that $\mathrm{H}_{2} \mathrm{~S}$ and sulfane sulfur levels in the DATStreated group were also significantly higher than those in the vehicle-treated group.

Furthermore, our results show that in U87MG as well as SH-SY5Y cells, DATS-induced inhibition of proliferation is associated with inactivation (phosphorylation) of $\mathrm{Bcl}-2$ (Fig. 2). Previous studies indicate downregulation of Bcl-2 in the presence of DATS in human pancreatic (Ma et al. 2014), epithelial ovarian (Wan et al. 2013), leukemia (Choi and Park 2012), lung (Li et al. 2012), breast (Malki et al. 2009), and prostate (Kim et al. 2007) cancer cell lines. $\mathrm{Bcl}-2$ protein contains four Bcl-2 homology domains with two cysteine residues at position 158 in the $\alpha 5$ domain and position 229 in the carboxyl-terminal membrane anchor domain (Cys-158 and Cys-229) (Luanpitpong et al. 2013). 
(a)

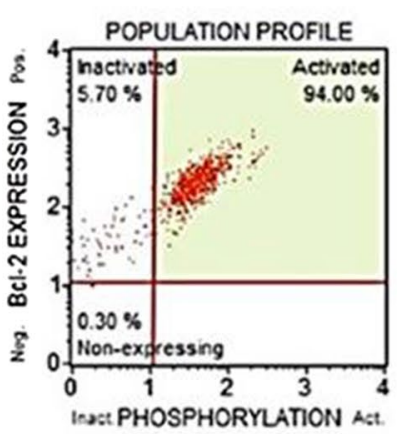

U87MG $100 \mu \mathrm{M}$ DATS 24h

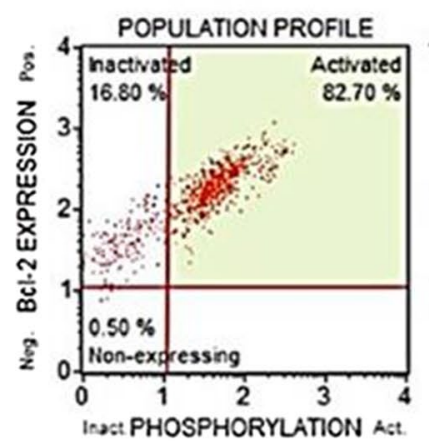

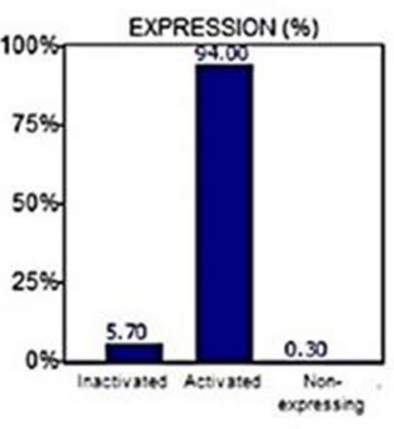

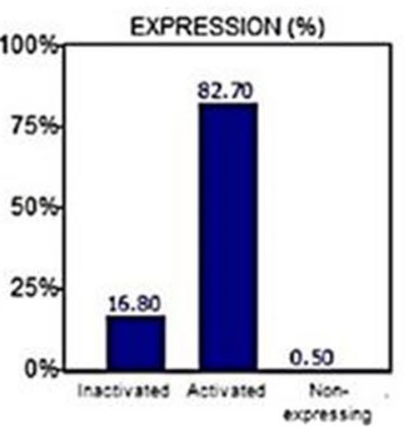

U87MG Control $48 \mathrm{~h}$
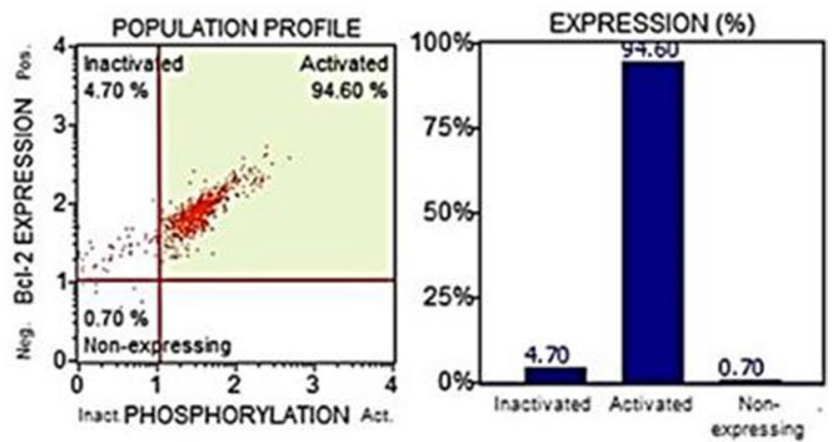

U87MG $100 \mu \mathrm{M}$ DATS 48h
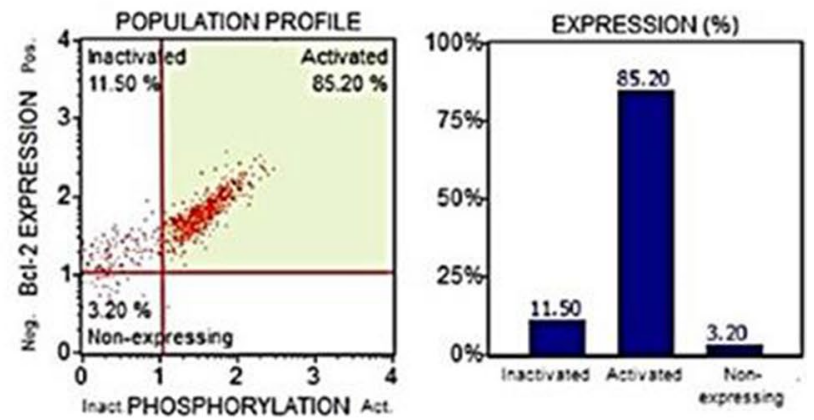

(b) Effect of DATS on Bcl-2 expression in U87MG cells

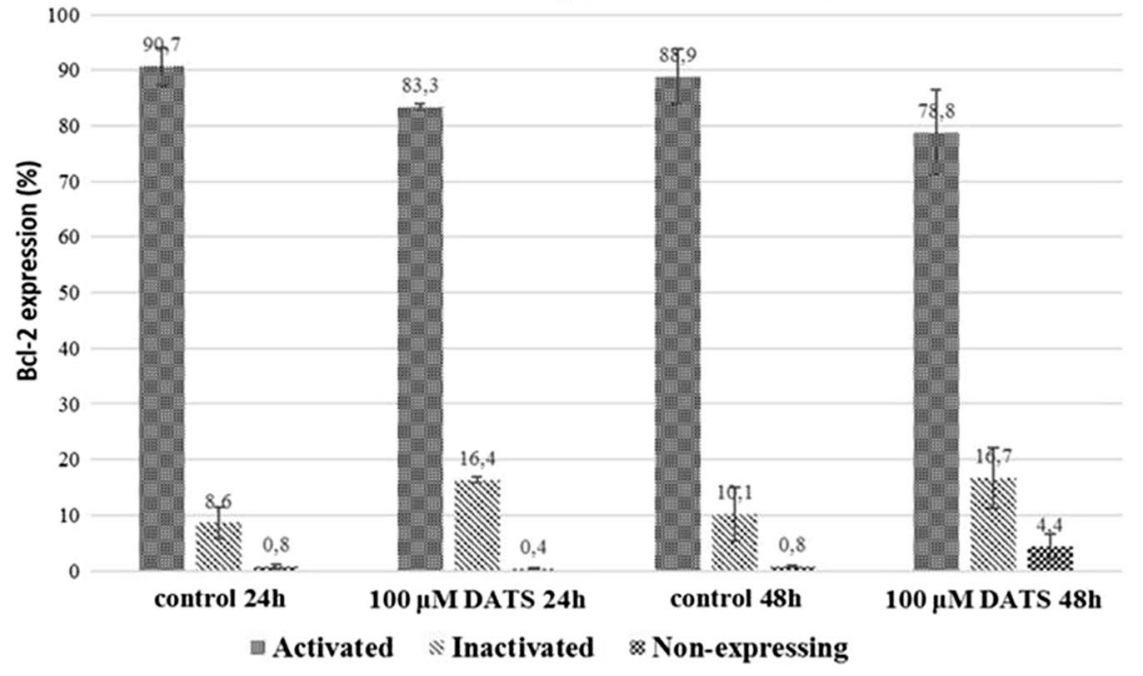

Fig. 2 Effect of diallyl trisulfide on expression of Bcl-2 in U87MG cells. The cells were treated with $100 \mu \mathrm{M}$ DATS for 24 and $48 \mathrm{~h}$. Bcl-2 expression was analyzed using a Muse ${ }^{\mathrm{TM}} \mathrm{Bcl}-2$ Activation Dual

Azad et al. (2006) demonstrated that the two cysteine residues of Bcl-2 were important in the $S$-nitrosylation. Thus, it appears that modification of the Bcl-2 cysteine residues via $\mathrm{S}$-sulfuration $(-\mathrm{SH} \rightarrow-\mathrm{SSH}$ ) (Fig. 5) might be possible, especially in U87MG cells, in which DATS induces an increase in the MPST activity (enzyme responsible for
Detection Kit. The samples were analyzed by flow cytometry. a One set of representative results is shown. b Each point represents the mean $\pm \mathrm{SD}$ of three independent experiments

the production and transfer of sulfane sulfur atoms) and sulfane sulfur level (Fig. 4a). Further studies will allow for explaining whether such a modification of Bcl-2 might be associated with the observed drop in Bcl-2 activity (Fig. 2) and inhibition of U87MG cells proliferation (Fig. 1). 
(a) SHSY5Y Control 24h
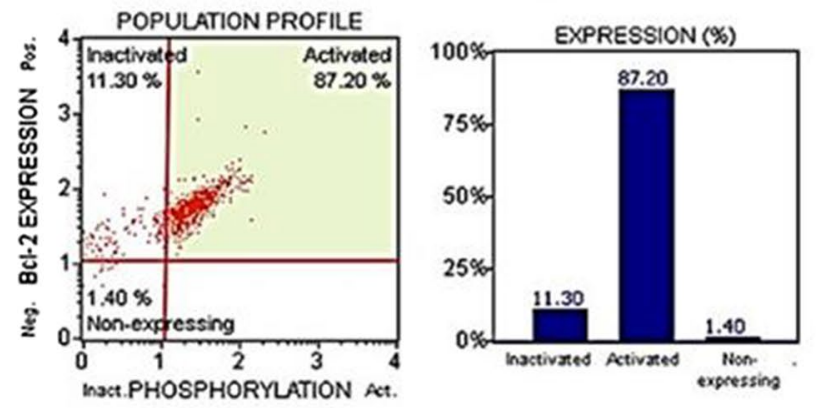

SHSY5Y Control 48h

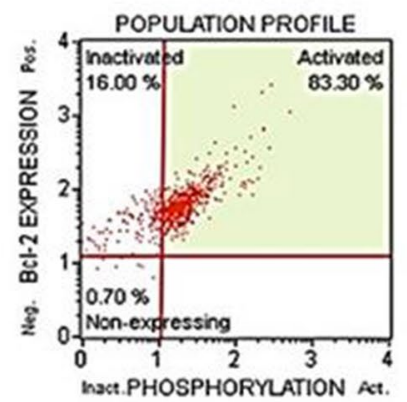

SHSY5Y DATS 24h

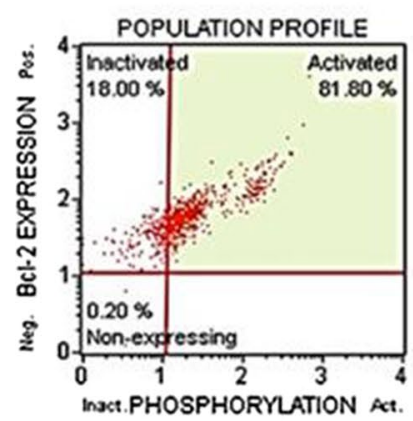

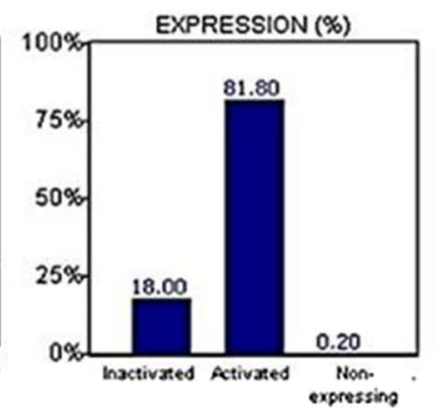
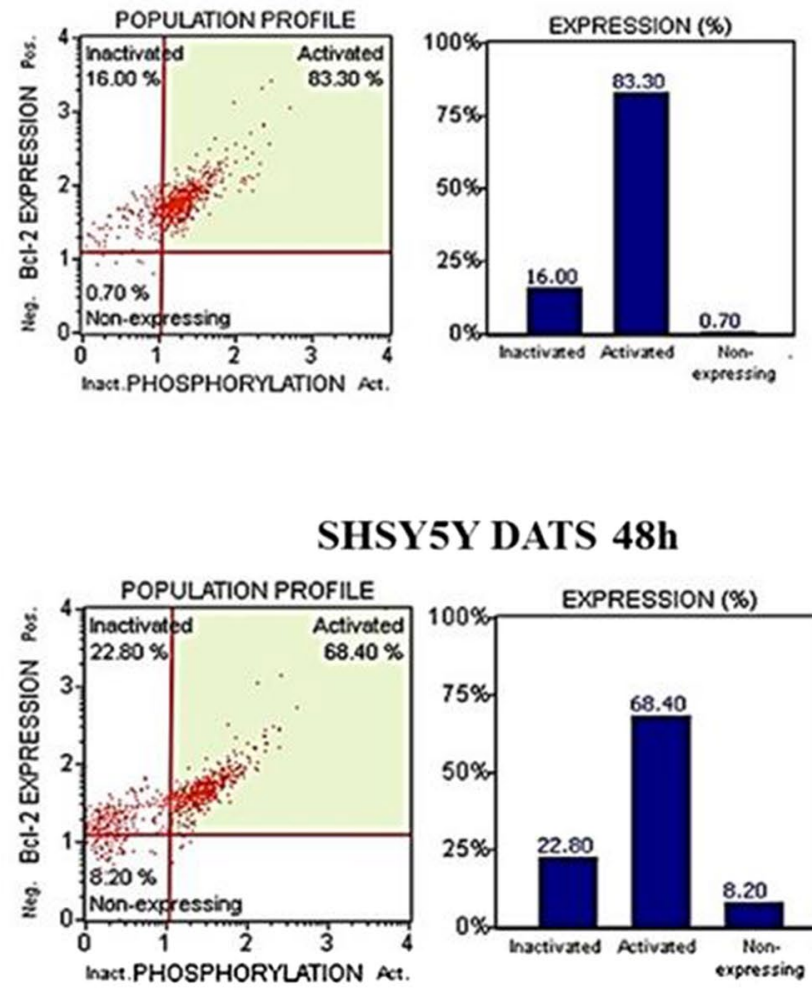

(b)

Effect of DATS on Bcl-2 expression in SH-SY5Y cells

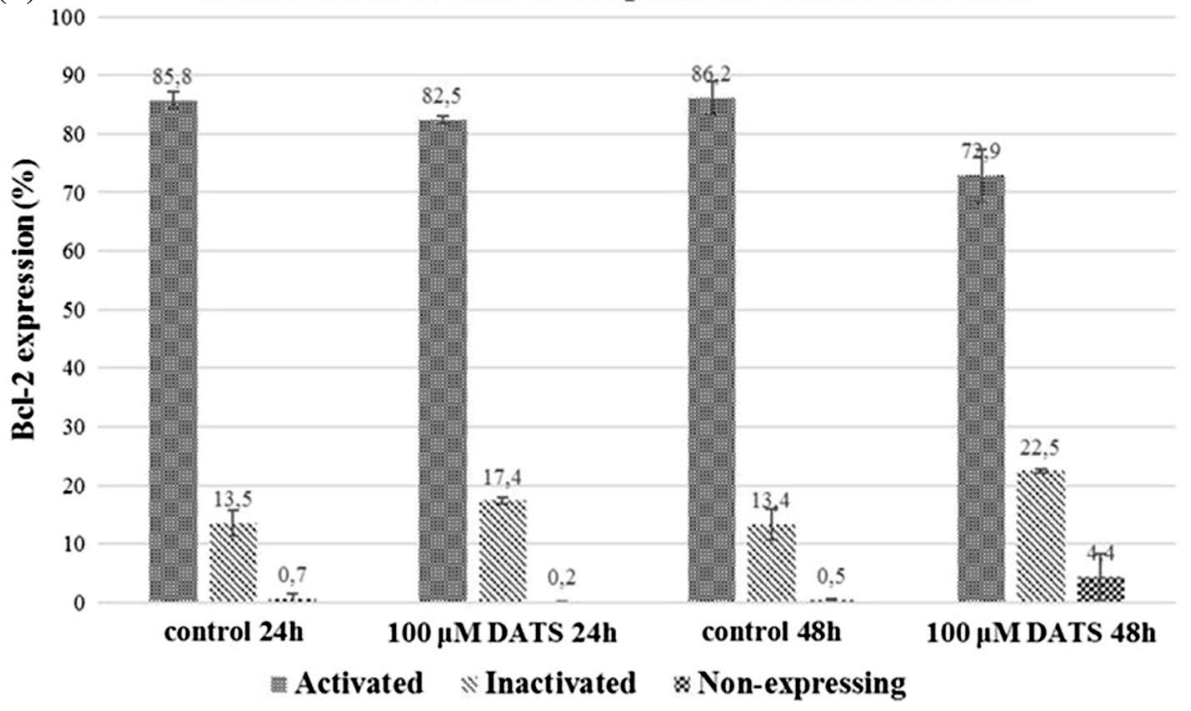

Fig. 3 Effect of diallyl trisulfide on expression of Bcl-2 in SH-SY5Y cells. The cells were treated with $100 \mu \mathrm{M}$ DATS for 24 and $48 \mathrm{~h}$. Bcl-2 expression was analyzed using a Muse ${ }^{\mathrm{TM}} \mathrm{Bcl}-2$ Activation Dual

The observed inhibition of SH-SY5Y cells proliferation by DATS (Fig. 1) can result from production of reactive oxygen species (ROS). In SH-SY5Y cells, in which the intracellular level of L-cysteine is very low (Table 2),
Detection Kit. The samples were analyzed by flow cytometry. a One set of representative results is shown. b Each point represents the mean \pm SD of three independent experiments

inactivation (phosphorylation) of Bcl-2 caused by DATS could be probably associated with ROS production and activation of stress kinases (Fig. 5). Das et al. (2007) showed that garlic compounds (diallyl sulfide, diallyl 

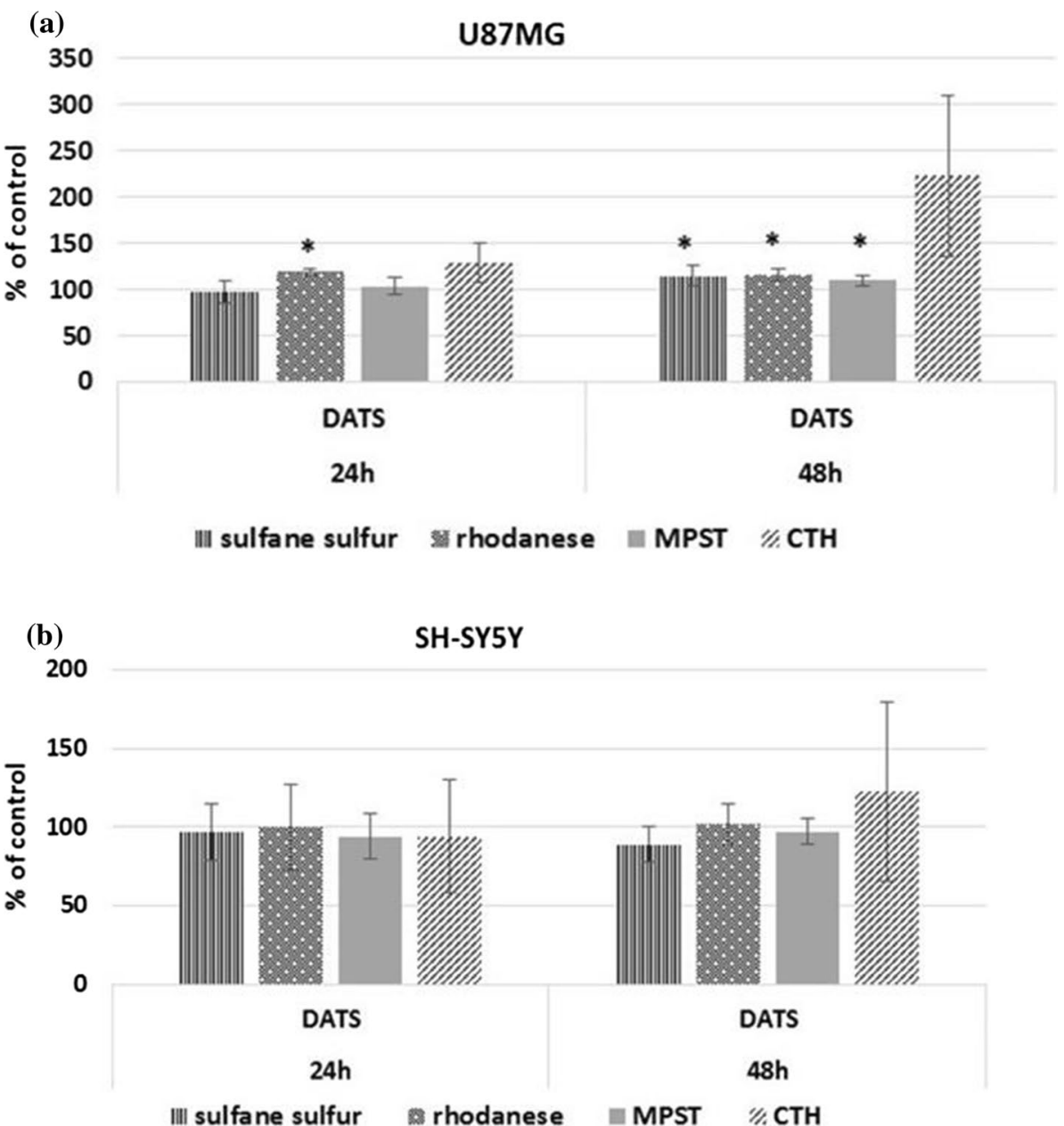

Fig. 4 The effect of diallyl trisulfide on sulfurtransferases activity and sulfane sulfur levels in U87MG (a) and SH-SY5Y (b). The cells were treated with $100 \mu \mathrm{M}$ DATS for 24 and $48 \mathrm{~h}$. The values are mean \pm SD from three independent experiments. In U87MG cells, rhodanese, MPST, and CTH activities determined after $24 \mathrm{~h}$ of culture equaled, respectively, $26 \pm 1,195 \pm 13$, and $1.2 \pm 0.4 \mathrm{nmole} / \mathrm{mg}$ protein $\times \min ^{-1}$ (control values), and $31 \pm 3,208 \pm 10$, and $0.7 \pm 0.3$ nmole/mg protein $\times \min ^{-1}$ after $48 \mathrm{~h}$ (control values). Sulfane sulfur level determined after 24 and $48 \mathrm{~h}$ of culture equaled, respec- tively, $130 \pm 20$ and $134 \pm 15 \mathrm{nmole} / \mathrm{mg}$ protein (control values). In SH-SY5Y cells, rhodanese, MPST, and CTH activities determined after $24 \mathrm{~h}$ of culture equaled, respectively, $67 \pm 7,889 \pm 120$, and $1.7 \pm 0.7 \mathrm{nmole} / \mathrm{mg}$ protein $\times \mathrm{min}^{-1}$ (control values), and $63 \pm 4$, $846 \pm 44$, and $1.3 \pm 0.6 \mathrm{nmole} / \mathrm{mg}$ protein $\times \mathrm{min}^{-1}$ after $48 \mathrm{~h}$ (control values). The sulfane sulfur level determined after 24 and $48 \mathrm{~h}$ of culture equaled, respectively, $134 \pm 26$, and $134 \pm 23 \mathrm{nmole} / \mathrm{mg}$ protein (control values)
Table 1 DATS effect on the intracellular level of GSH, GSSG, L-cysteine, L-cystine, and cystathionine in U87MG cells

\begin{tabular}{lllllc}
\hline $\begin{array}{l}\text { U87MG } \\
\text { cells }\end{array}$ & GSH & GSSG & L-Cysteine & L-Cystine & Cystathionine \\
\hline nmol/mg protein & & & & \\
Control 24 h & $21.9 \pm 6.3$ & $2.2 \pm 0.7$ & $1.0 \pm 0.1$ & $2.7 \pm 0.5$ & $0.05 \pm 0.01$ \\
DATS 24 h & $39.0 \pm 2.9^{*}$ & $4.5 \pm 0.1^{*}$ & $1.6 \pm 0.4$ & $2.5 \pm 0.1$ & $0.2 \pm 0.1$ \\
Control 48 h & $14.6 \pm 2.8$ & $1.5 \pm 0.3$ & $0.8 \pm 0.1$ & $1.4 \pm 0.3$ & $0.06 \pm 0.01$ \\
DATS 48 h & $26.7 \pm 1.7^{*}$ & $2.8 \pm 0.2^{*}$ & $1.2 \pm 0.2$ & $2.2 \pm 0.3^{*}$ & $0.1 \pm 0.03$ \\
\hline
\end{tabular}

The cells were incubated for $24 \mathrm{~h}$ and $48 \mathrm{~h}$ in the presence of $100 \mu \mathrm{M}$ DATS. Every value represents the mean \pm SD of three to five independent experiments

$* p<0.05$ (Student's $t$ test) 
Table 2 DATS effect on the intracellular level of GSH, GSSG, L-cysteine, L-cystine, and cystathionine in SH-SY5Y cells

\begin{tabular}{llllll}
\hline $\begin{array}{l}\text { SH-SY5Y } \\
\text { cells }\end{array}$ & GSH & GSSG & L-Cysteine & L-Cystine & Cystathionine \\
\hline nmol/mg protein & & & & & \\
Control 24 h & $2.3 \pm 0.3$ & $1.0 \pm 0.1$ & ND & $0.9 \pm 0.05$ & $0.7 \pm 0.1$ \\
DATS 24 h & $7.5 \pm 1.8^{*}$ & $1.8 \pm 0.5^{*}$ & ND & $2.6 \pm 0.1^{*}$ & $2.0 \pm 0.1^{*}$ \\
Control 48 h & $2.3 \pm 0.1$ & $1.0 \pm 0.1$ & ND & $1.1 \pm 0.02$ & $0.7 \pm 0.04$ \\
DATS 48 h & $7.0 \pm 0.9^{*}$ & $2.2 \pm 0.2^{*}$ & ND & $2.0 \pm 0.2^{*}$ & $1.9 \pm 0.1^{*}$ \\
\hline
\end{tabular}

The cells were incubated for $24 \mathrm{~h}$ and $48 \mathrm{~h}$ in the presence of $100 \mu \mathrm{M}$ DATS. Every value represents the mean $\pm \mathrm{SD}$ of three to five independent experiments. The level of L-cysteine was not detected (ND) in these cells

$* p<0.05$ (Student's $t$ test)
Fig. 5 Suggested mechanisms of inhibition of U87MG and SH-SY5Y cells proliferation by diallyl trisulfide. *These reactions were confirmed by Das et al. (2007) and by **Xiao et al. (2004). The dashed lines show the suggested reactions

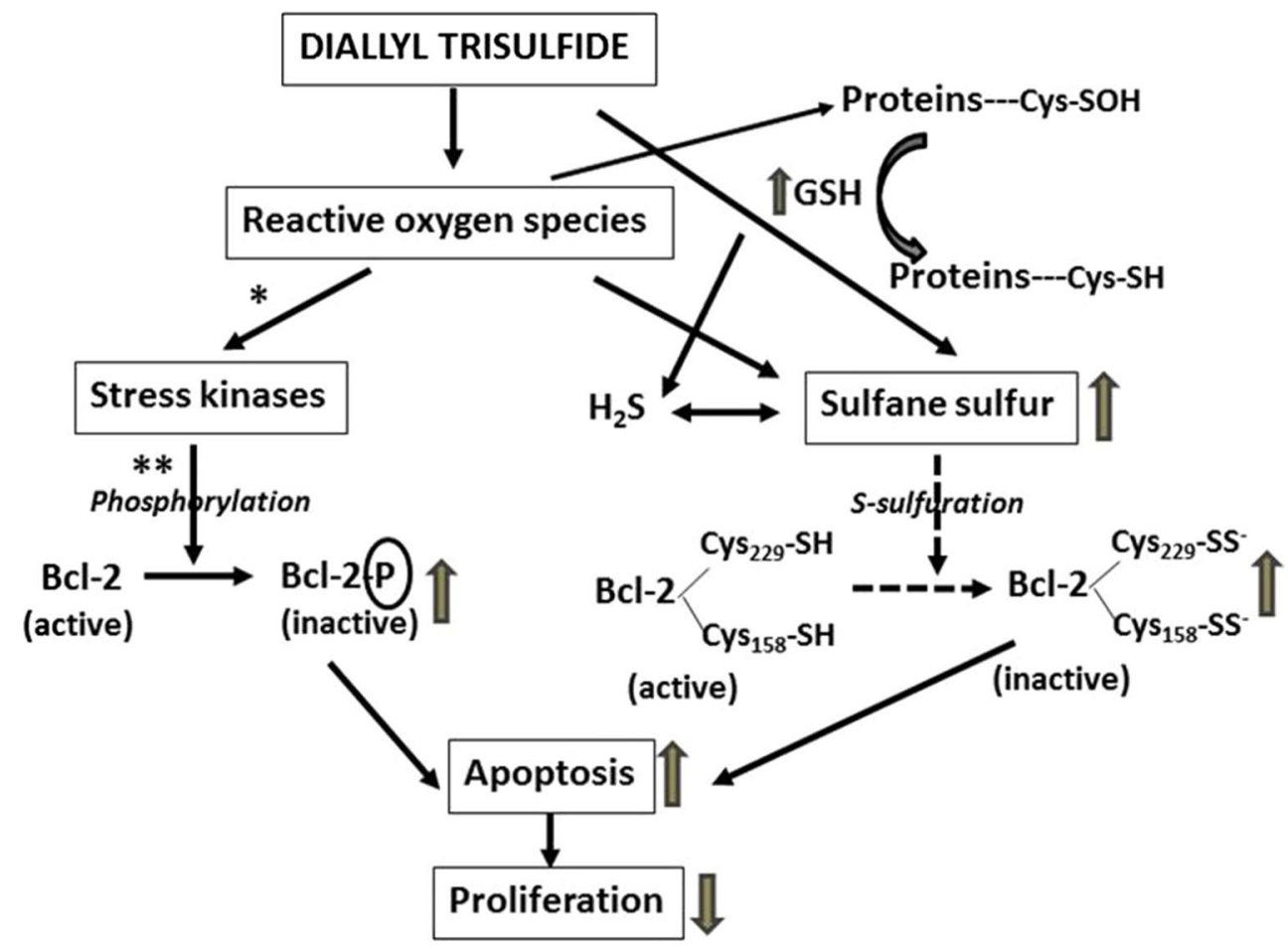

disulfide) induced apoptosis in glioblastoma cells due to production of ROS, an increase in endoplasmic reticulum stress, a decrease in mitochondrial membrane potential, and activation of stress kinases and cysteine proteases. Treatment of glioblastoma cells with diallyl sulfide and diallyl disulfide induced an increase in phosphorylation of p38 MAPK and caused apoptosis (Das et al. 2007). Xiao et al. (2004) demonstrated that DATS-induced apoptosis in prostate cancer (PC-3) cells was associated with activation of extracellular signal-regulated kinase 1/2 (ERK1/2) and c-jun N-terminal kinase 1 (JNK1) and/or JNK2. Phosphorylation of $\mathrm{Bcl}-2$ reduced its interaction with $\mathrm{Bax}$ to trigger mitochondrial caspase cascade.

\section{Antioxidative effect of diallyl trisulfide on U87MG and SH-SY5Y cells}

Diallyl trisulfide has antioxidant effect on U87MG and SHSY5Y cells by increasing the level of cystathionine and the level of GSH (Tables 1, 2), the most important intracellular thiolic antioxidant. GSH is a major determinant of the thiol/disulfide redox state, and a critical regulator of immune function, cell senescence, apoptosis, and vital redox-sensitive signaling pathways. It is highly likely that $\mathrm{H}_{2} \mathrm{~S}$ formation from sulfane sulfur requires $\mathrm{GSH}$ as both hydrogen and electron donor (Predmore et al. 2012a, b). It was reported that DATS led to an increase in glutathione 
peroxidase and thioredoxin reductase activity in human lung cancer A549 cells; the glutathione reductase activity was decreased (Hu et al. 2007). In rat primary hepatocytes, DATS could enhance antioxidation and detoxification capabilities by increasing the intracellular GSH level and the activity of glutathione peroxidase, glutathione reductase, or glutathione S-transferase (Wu et al. 2004). DATS reduced levels of malondialdehyde, asymmetric dimethylarginine, and acetylcholinestrase activity, while increasing GSH levels (Mostafa et al. 2016). DATS inhibited oxidative stress and apoptosis in an ethanol-induced model (Chen et al. 2016), and had a protective effect against arsenic-induced oxidative stress in rat erythrocytes and lymphocytes (Prabu and Sumedha 2014). The levels of lipid peroxidation markers, such as thiobarbituric acid reactive substances, malondialdehyde, lipid hydroperoxides, conjugated dienes and protein carbonyl, were significantly decreased and there was a significant increase in ATPase activities and non-enzymatic and enzymatic antioxidants on treatment with DATS in a dose-related manner (Prabu and Sumedha 2014).

Our results confirm the antioxidant properties of diallyl trisulfide. It induces rhodanese and MPST activity in U87MG cells (Fig. 4a). The rhodanese participates in sulfane sulfur metabolism (Ubuka et al. 2008) and is one of the enzymes able to catalyze $\mathrm{H}_{2} \mathrm{~S}$ formation, in the presence of thiosulfate and dithiothreitol (Mikami et al. 2011). MPST is a protein closely related to rhodanese (Nakajima 2015). Rhodanese, similarly to MPST, can generate $\mathrm{H}_{2} \mathrm{~S}$ reacting with thioredoxin (Mikami et al. 2011; Yadav et al. 2013). Thus, rhodanese could be involved in both the metabolism of organosulfur compounds and in the production of $\mathrm{H}_{2} \mathrm{~S}$ in mitochondria (Bhuiyan et al. 2015). Since it has also been demonstrated that MPST has a role in antioxidative defense systems (Nagahara et al. 2007, 2013), both MPST and rhodanese could also serve as antioxidant proteins (Nakajima 2015). When MPST and rhodanese are oxidized, catalytic site cysteines are reversibly converted to sulfenyl (Nagahara 2011). Stable and low redox sulfenate is formed and then is reduced by thioredoxin (Nagahara et al. 2007, 2013; Nagahara 2011). Under oxidizing conditions, the cysteine pool is increased because of post-translational regulation of methionine synthase (Mosharov et al. 2000), cystathione $\beta$-synthase (Taoka et al. 1998) and MPST (Nagahara et al. 2015; Nagahara and Katayama 2005). An increase in the cysteine content in the cell results in an increase in the content of cellular reductants, such as thioredoxin and glutathione. Thus, MPST and rhodanese serve as antioxidant proteins and partly maintain cellular redox homeostasis (Nagahara 2011). Krueger et al. (2010) demonstrated that the reduction of rhodanese expression indicated an increase of oxidative stress and predicted mortality in hemodialysis patients. Additionally, administration of sodium thiosulfate, a substrate of rhodanese, prevented acute inflammatory liver failure by augmenting thiosulfate levels and upregulating antioxidant and anti-apoptotic defense in the liver (Shirozu et al. 2014).

\section{Conclusions}

Diallyl trisulfide inhibits proliferation of U87MG and SHSY5Y cancer cells. In U87MG cells, in the presence of an increased activity of MPST and rhodanese and an increased sulfane sulfur level, the sulfhydryl groups of Bcl-2 can be modified via S-sulfuration (Fig. 5). Through its effect on inactivation of Bcl-2, the modification can inhibit proliferation of these cells. In SH-SY5Y cells, where cysteine level is negligible, inactivation of $\mathrm{Bcl}-2$ protein following DATS administration can result from an increased level of reactive oxygen species.

The antioxidative potential of DATS is supported by an elevated level of glutathione and cystathionine, as well as an increased activity of MPST and rhodanese in the cells.

Acknowledgements This work was supported by a grant from the National Committee for Scientific Research No. K/ZDS/002314; K/ ZDS/005887.

Author contributions Conceived and designed the experiments: HJ. Performed the experiments: HJ; MK-K; EJ-G. Analyzed the data: HJ. Wrote the paper: HJ, MW.

\section{Compliance with ethical standards}

Conflict of interest The authors declare no conflict of interest.

Ethical standards This article does not contain any studies with human participants or animals performed by any of the authors.

Open Access This article is distributed under the terms of the Creative Commons Attribution 4.0 International License (http://creativecommons.org/licenses/by/4.0/), which permits unrestricted use, distribution, and reproduction in any medium, provided you give appropriate credit to the original author(s) and the source, provide a link to the Creative Commons license, and indicate if changes were made.

\section{References}

Azad N, Vallyathan V, Wang L, Tantishaiyakul V, Stehlik C, Leonard SS, Rojanasakul Y (2006) S-nitrosylation of Bcl-2 inhibits its ubiquitin-proteasomal degradation. A novel antiapoptotic mechanism that suppresses apoptosis. J Biol Chem 281:34124-34134

Benavides GA, Squadrito GL, Mills RW, Patel HD, Isbell TS, Patel RP, Darley-Usmar VM, Doeller JE, Kraus DW (2007) Hydrogen sulfide mediates the vasoactivity of garlic. Proc Natl Acad Sci USA 104:17977-17982

Bhuiyan AI, Papajani VT, Paci M, Melino S (2015) Glutathione-garlic sulfur conjugates: slow hydrogen sulfide releasing agents for therapeutic applications. Molecules 20:1731-1750 
Borkowska A, Sielicka-Dudzin A, Herman-Antosiewicz A, Wozniak M, Fedeli D, Falcioni G, Antosiewicz J (2012) Diallyl trisulfideinduced prostate cancer cell death is associated with $\mathrm{Akt} / \mathrm{PKB}$ dephosphorylation mediated by Pp66shc. Eur J Nutr 51:817-825

Bronowicka-Adamska P, Zagajewski J, Czubak J, Wróbel M (2011) RP-HPLC method for quantitative determination of cystathionine, cysteine and glutathione: an application for the study of the metabolism of cysteine in human brain. J Chromatogr B Analyt Technol Biomed Life Sci 879:2005-2009

Capasso A (2013) Antioxidant action and therapeutic efficacy of Allium sativum L. Molecules 18:690-700

Chandra-Kuntal K, Lee J, Singh SV (2013) Critical role for reactive oxygen species in apoptosis induction and cell migration inhibition by diallyl trisulfide, a cancer chemopreventive component of garlic. Breast Cancer Res Treat 138:69-79

Chen LY, Chen Q, Zhu XJ, Kong DS, Wu L, Shao JJ, Zheng SZ (2016) Diallyl trisulfide protects against ethanol-induced oxidative stress and apoptosis via a hydrogen sulfide-mediated mechanism. Int Immunopharmacol 36:23-30

Choi YH, Park HS (2012) Apoptosis induction of U937 human leukemia cells by diallyl trisulfide induces through generation of reactive oxygen species. J Biomed Sci 19:50

Czubak J, Wróbel M, Jurkowska H (2002) Cystathionine $\gamma$-lyase (EC 4.4.1.1): an enzymatic assay of $\alpha$-ketobutyrate using lactate dehydrogenase. Acta Biol Crac Ser Zool 44:113-117

Das A, Banik NL, Ray SK (2007) Garlic compounds generate reactive oxygen species leading to activation of stress kinases and cysteine proteases for apoptosis in human glioblastoma T98G and U87MG cells. Cancer 110:1083-1095

Dominick PK, Cassidy PB, Roberts JC (2001) A new and versatile method for determination of thiolamines of biological importance. J Chromatogr B Biomed Sci Appl 761:1-12

Gillies RJ, Didier N, Denton M (1986) Determination of cell number in monolayer cultures. Anal Biochem 159:109-113

Hahm ER, Singh SV (2014) Diallyl trisulfide inhibits estrogen receptor- $\alpha$ activity in human breast cancer cells. Breast Cancer Res Treat 144:47-57

Hu Y, Urig S, Koncarevic S, Wu X, Fischer M, Rahlfs S, MerschSundermann V, Becker K (2007) Glutathione- and thioredoxin related enzymes are modulated by sulfur-containing chemopreventive agents. Biol Chem 388:1069-1081

Hung FM, Shang HS, Tang NY, Lin JJ, Lu KW, Lin JP, Ko YC, Yu CC, Wang HL, Liao JC, Lu HF, Chung JG (2014) Effects of diallyl trisulfide on induction of apoptotic death in murine leukemia WEHI- 3 cells in vitro and alterations of the immune responses in normal and leukemic mice in vivo. Environ Toxicol 30:1343-1353

Jurkowska H, Wróbel M (2008) N-acetyl-L-cysteine as a source of sulfane sulfur in astrocytoma and astrocyte cultures: correlations with cell proliferation. Amino Acids 34:231-237

Jurkowska H, Placha W, Nagahara N, Wróbel M (2011a) The expression and activity of cystathionine-c-lyase and 3-mercaptopyruvate sulfurtransferase in human neoplastic cell lines. Amino Acids 41:151-158

Jurkowska H, Uchacz T, Roberts J, Wróbel M (2011b) Potential therapeutic advantage of ribose-cysteine in the inhibition of astrocytoma cell proliferation. Amino Acids 41:131-139

Jurkowska H, Roman HB, Hirschberger LL, Sasakura K, Nagano T, Hanaoka K, Krijt J, Stipanuk MH (2014) Primary hepatocytes from mice lacking cysteine dioxygenase show increased cysteine concentrations and higher rates of metabolism of cysteine to hydrogen sulfide and thiosulfate. Amino Acids 46:1353-1365

Kim YA, Xiao D, Xiao H, Powolny AA, Lew KL, Reilly ML, Zeng Y, Wang Z, Singh SV (2007) Mitochondria-mediated apoptosis by diallyl trisulfide in human prostate cancer cells is associated with generation of reactive oxygen species and regulated by Bax/Bak. Mol Cancer Ther 6:1599-1609
Kolluru GK, Shen X, Bir SC, Kevil CG (2013) Hydrogen sulfide chemical biology: pathophysiological roles and detection. Nitric Oxide 35:5-20

Krueger K, Koch K, Juehling A, Tepel M, Scholze A (2010) Low expression of thiosulfate sulfurtransferase (rhodanese) predicts mortality in hemodialysis patients. Clin Biochem 43:95-101

Kuo WW, Wang WJ, Tsai CY, Way CL, Hsu HH, Chen LM (2013) Diallyl trisufide (DATS) suppresses high glucose-induced cardiomyocyte apoptosis by inhibiting JNK/NFkappaB signaling via attenuating ROS generation. Int J Cardiol 168:270-280

Kusukawa J, Suefuji Y, Ryu F, Noguchi R, Iwamoto O (2000) Kameyama, T. Dissemination of cancer cells into circulation occurs by incisional biopsy of oral squamous cell carcinoma. J Oral Pathol Med 29:303-307

Lai KC, Hsu SC, Yang JS, Yu CC, Lein JC, Chung JG (2015) Diallyl trisulfide inhibits migration, invasion and angiogenesis of human colon cancer HT-29 cells and umbilical vein endothelial cells, and suppresses murine xenograft tumour growth. J Cell Mol Med 19:474-484

Levonen AL, Lapatto R, Saksela M, Raivi KO (2000) Human cystathionine $\gamma$-lyase: developmental and in vitro expression of two isoforms. Biochem J 347:291-295

Li W, Tian H, Li L, Li S, Yue W, Chen Z, Qi L, Hu W, Zhu Y, Hao B, Gao C, Si L, Gao F (2012) Diallyl trisulfide induces apoptosis and inhibits proliferation of A549 cells in vitro and in vivo. Acta Biochim Biophys Sin 44:577-583

Liang D, Wu H, Wong MW, Huang D (2015) Diallyl trisulfide is a fast $\mathrm{H}_{2} \mathrm{~S}$ donor, but diallyl disulfide is a slow one: the reaction pathways and intermediates of glutathione with polysulfides. Org Lett 17:4196-4199

Liu Y, Zhu P, Wang Y, Wei Z, Tao L, Zhu Z, Sheng X, Wang S, Ruan J, Liu Z, Cao Y, Shan Y, Sun L, Wang A, Chen W, Lu Y (2015) Antimetastatic therapies of the polysulfide diallyl trisulfide against triple-negative breast cancer (TNBC) via suppressing MMP2/9 by blocking NF- $\mathrm{BB}$ and ERK/MAPK signaling pathways. PLoS ONE 10:e0123781

Liu M, Wu L, Montaut S, Yang G (2016) Hydrogen sulfide signaling axis as a target for prostate cancer therapeutics. Prostate cancer. dx. doi:10.1155/2016/8108549

Lowry OH, Rosebrough NJ, Farr L, Randall RJ (1951) Protein measurement with the folin phenol reagent. J Biol Chem 193:265-275

Luanpitpong S, Chanvorachote P, Stehlik C, Tse W, Callery PS, Wang L, Rojanasakul Y (2013) Regulation of apoptosis by Bcl-2 cysteine oxidation in human lung epithelial cells. Mol Biol Cell 24:858-869

Ma HB, Huang S, Yin XR, Zhang Y, Di ZL (2014) Apoptotic pathway induced by diallyl trisulfide in pancreatic cancer cells. World $\mathrm{J}$ Gastroenterol 20:193-203

Malki A, El-Saadani M, Sultan AS (2009) Garlic constituent diallyl trisulfide induced apoptosis in MCF7 human breast cancer cells. Cancer Biol Ther 8:2174-2184

Matsuo Y, Greenberg DM (1958) A crystalline enzyme that cleaves homoserine and cystathionine: i. Isolation procedure and some physiochemical properties. J Biol Chem 230:545-560

Mikami Y, Shibuya N, Kimura Y, Nagahara N, Ogasawara Y, Kimura H (2011) Thioredoxin and dihydrolipoic acid are required for 3 mercaptopyruvate sulfurtransferase to produce hydrogen sulfide. Biochem J 439:479-485

Mosharov E, Cranford MR, Banerjee R (2000) The quantitatively important relationship between homocysteine metabolism and glutathione synthesis by the transsulfuration pathway and its regulation by redox changes. Biochemistry 39:13005-13011

Mostafa DK, El Azhary NM, Nasra RA (2016) The hydrogen sulfide releasing compounds ATB-346 and diallyl trisulfide attenuate streptozotocin-induced cognitive impairment, neuroinflammation, and 
oxidative stress in rats: involvement of asymmetric dimethylarginine. Can J Physiol Pharmacol 94:699-708

Nagahara N (2011) Catalytic site cysteines of thiol enzyme: sulfurtransferases. J Amino Acids, 709404

Nagahara N, Katayama A (2005) Post-translational regulation of mercaptopyruvate sulfurtransferase via a low redox potential cysteinesulfenate in the maintenance of redox homeostasis. J Biol Chem 280:34569-34576

Nagahara N, Yoshii T, Abe Y, Matsumura T (2007) Thioredoxin-dependent enzymatic activation of mercaptopyruvate sulfurtransferase - An intersubunit disulfide bond serves as a redox switch for activation. $\mathrm{J}$ Biol Chem 282:1561-1569

Nagahara N, Nagano M, Ito T, Shimamura K, Akimoto T, Suzuki H (2013) Antioxidant enzyme, 3-mercaptopyruvate sulfurtransferaseknockout mice exhibit increased anxiety-like behaviors: a model for human mercaptolactate-cysteine disulfiduria. Sci Rep 3:1986

Nagahara N, Nagano M, Ito T, Suzuki H (2015) Redox regulation of mammalian 3-mercaptopyruvate sulfurtransferase. Methods Enzymol 554:229-254

Nakajima T (2015) Roles of sulfur metabolism and rhodanese in detoxification and anti-oxidative stress functions in the liver: responses to radiation exposure. Med Sci Monit 21:1721-1725

Nkrumah-Elie YM, Reuben JS, Hudson A, Taka E, Badisa R, Ardley T, Israel B, Sadrud-Din SY, Oriaku E, Darling-Reed SF (2012) Diallyl trisulfide as an inhibitor of benzo(a)pyreneinduced precancerous carcinogenesis in MCF-10A cells. Food Chem Toxicol 50:2524-2530

Pandrangi A (2015) Cancer Chemoprevention by Garlic - A Review Hereditary Genet 4:147

Prabu SM, Sumedha NC (2014) Ameliorative effect of diallyl trisulphide on arsenic-induced oxidative stress in rat erythrocytes and DNA damage in lymphocytes. J Basic Clin Physiol Pharmacol 25:181-197

Predmore BL, Kondo K, Bhushan S, Zlatopolsky MA, King AL, Aragon JP, Grinsfelder DB, Condit ME, Lefer DJ (2012a) The polysulfide diallyl trisulfide protects the ischemic myocardium by preservation of endogenous hydrogen sulfide and increasing nitric oxide bioavailability. Am J Physiol Heart Circ Physiol 302:H2410-H2418

Predmore BL, Lefer DJ, Gojon G (2012b) Hydrogen sulfide in biochemistry and medicine. Antioxid Redox Signal 17:119-140

Seki T, Hosono T, Hosono-Fukao T, Inada K, Tanaka R, Ogihara J, Ariga $\mathrm{T}$ (2008) Anticancer effects of diallyl trisulfide derived from garlic. Asian Pac J Clin Nutr 17:249-252

Shankar S, Chen Q, Ganapathy S, Singh KP, Srivastava RK (2008) Diallyl trisulfide increases the effectiveness of TRAIL and inhibits prostate cancer growth in an orthotopic model: molecular mechanisms. Mol Cancer Ther 7:2328-2338

Shin DY, Kim G-Y, Hwang HJ, Kim WJ, Choi YH (2014) Diallyl trisulfide-induced apoptosis of bladder cancer cells is caspase-dependent and regulated byPI3 K/Akt and JNK pathways. Environ Toxicol Pharmacol 37:74-83

Shirozu K, Tokuda K, Marutani E (2014) Cystathionine $\gamma$-lyase deficiency protects mice from galactosamine/lipopolysaccharide induced acute liver failure. Antioxid Redox Signal 20:204-216

Stein A, Bailey SM (2013) Redox biology of hydrogen sulfide: implications for physiology, pathophysiology, and pharmacology. Redox Biol 1:32-39

Sörbo B (1955) Rhodanese. Methods Enzymol 2:334-337

Taoka S, Ohja S, Shan X, Kruger WD, Banerjee R (1998) Evidence for heme-mediated redox regulation of human cystathionine betasynthase activity. J Biol Chem 273:25179-25184
Toohey JI, Cooper AJL (2014) Thiosulfoxide (sulfane) sulfur: new chemistry and new regulatory roles in biology. Molecules 19:12789-12813

Tsai CY, Wen SY, Shibu MA, Yang YC, Peng H, Wang B, Wei YM, Chang HY, Lee CY, Huang CY, Kuo WW (2015) Diallyl trisulfide protects against high glucose-induced cardiac apoptosis by stimulating the production of cystathionine gamma-lyase-derived hydrogen sulfide. Int J Cardiol 195:300-310

Ubuka T, Okada A, Nakamura H (2008) Production of hypotaurine from L-cysteinesulfinate by rat liver mitochondria. Amino Acids 35:53-58

Valentine WN, Frankenfeld JK (1974) 3-Mercaptopyuruvate sulfurtransferase (EC 2.8.1.2): a simple assay adapted to human blood cells. Clin Chim Acta 51:205-210

Wallace GC, Haar CP, Vandergrift WA, Giglio P, Dixon-Mah YN, Varma AK, Ray SK, Patel SJ, Banik NL, Das A (2013) Multi-targeted DATS prevents tumor progression and promotes apoptosis in ectopic glioblastoma xenografts in SCID mice via HDAC inhibition. J Neurooncol 114:43-50

Wan HF, Yu LH, Wu JL, Tu S, Zhu WF, Zhang XL, Wan FS (2013) Effect of diallyl trisulfide on human ovarian cancer SKOV-3/DDP Cell Apoptosis. Asian Pac J Cancer Prev 14:7197-7201

Wood L (1987) Sulfane sulfur. Methods Enzymol 143:25-29

Wróbel M, Jurkowska H, Śliwa L, Srebro Z (2004) Sulfurtransferases and cyanide detoxification in mouse liver, kidney, and brain. Toxicol Mech Methods 14:331-337

Wu CC, Lii CK, Tsai SJ, Sheen LY (2004) Diallyl trisulfide modulates cell viability and the antioxidation and detoxification systems of rat primary hepatocytes. J Nutr 134:724-728

Xiao D, Choi S, Johnson DE, Vogel VG, Johnson CS, Trump DL, Lee YJ, Singh SV (2004) Diallyl trisulfide-induced apoptosis in human prostate cancer cells involves c-Jun N-terminal kinase and extracellular-signal regulated kinase-mediated phosphorylation of Bcl-2. Oncogene 23:5594-5606

Xiao D, Lew KL, Kim YA, Zeng Y, Hahm ER, Dhir R, Singh SV (2006) Diallyl trisulfide suppresses growth of PC-3 human prostate cancer xenograft in vivo in association with Bax and Bak induction. Clin Cancer Res 12:6836-6843

Yadav PK, Yamada K, Chiku T, Koutmos M, Banerjee R (2013) Structure and kinetic analysis of $\mathrm{H} 2 \mathrm{~S}$ production by human mercaptopyruvate sulfurtransferase. J Biol Chem 288:20002-20013

Yang JB, Wei DY, Wu ZY, Xu SH (2012) DATS suppresses invasion of oral squamous cell carcinoma cel lines by reducing matrix metalloproteinase-9 via PI3 K/AKT. Turk J Biol 36:506-512

Zeng T, Zhang CL, Zhu ZP, Yu LH, Zhao XL, Xie KQ (2008) Diallyl trisulfide (DATS) effectively attenuated oxidative stress-mediated liver injury and hepatic mitochondrial dysfunction in acute ethanolexposed mice. Toxicology 252:86-91

Zhang F, Zhang Y, Wang K, Liu G, Yang M, Zhao Z, Li S, Cai J, Cao J (2016) Protective effect of diallyl trisulfide against naphthaleneinduced oxidative stress and inflammatory damage in mice. Int $\mathrm{J}$ Immunopathol Pharmacol 29:205-216

Zhao Y, Biggs TD, Xian M (2014) Hydrogen sulfide $\left(\mathrm{H}_{2} \mathrm{~S}\right)$ releasing agents: chemistry and biological applications. Chem Commun (Camb) 50:11788-11805

Zhou C, Mao XP, Guo Q, Zeng FQ (2009) Diallyl trisulphide-induced apoptosis in human melanoma cells involves downregulation of Bcl-2 and Bcl-xL expression and activation of caspases. Clin Exp Dermatol 34:e537-e543 